\title{
Cholesterol Sensitivity of Polypyrrole Films Containing Immobilized Cholesterol Oxidase and an Electron Mediator
}

\author{
Yoshio KAJIYA, Ryo TSUDA and Hiroshi YONEYAMA*
}

Received June 7, 1990 ; Accepted July 20, 1990

\section{INTRODUCTION}

Much effort has been directed to the fabrication of the amperometric sensors using the immobilized enzyme ${ }^{1}$ ). In our previous study, it was demonstrated that both glucose oxidase and an electron mediator such as ferrocenecarboxylate and hydroquinonesulfonate can be immobilized in polypyrrole (PPy) films in the course of electropolymerization of pyrrole and the resulting PPy film exhibited the amperometric sensitivity to glucose without using any mediator in solution 2,3$)$. In this communication, the electrochemical immobilization of cholesterol oxidase ( $\mathrm{CHO}$ ) and ferrocenecarboxylate $\left(\mathrm{FC}_{\mathrm{C}}\right)$ in PPy films and the cholesterol sensitivity of the resulting PPy films are described.

\section{FXPERTMETITAL}

Cholesterol oxidase (EC.1.1.3.6) from Pseudomonas sp. was purchased from Wako Pure Chemical. (3.2 $\left.\mathrm{J}^{\mathrm{mg}^{-1}}\right)$ Simultaneous immobilization of $\mathrm{CHO}$ and $\mathrm{Fc}$ in $\mathrm{PPy}$ films was accomplished by the electropolymerization of $0.1 \mathrm{M}\left(\mathrm{M} \equiv \mathrm{mol} \mathrm{dm}^{-3}\right)$ pyrrole in the presence of $0.5 \mathrm{~g} \mathrm{dm}^{-3} \mathrm{CHO}$ and $5 \times 10^{-4} \mathrm{M} \mathrm{FC}$ at various current densities. The solution $\mathrm{pH}$ was adjusted to $\mathrm{pH} 8-8.5$ and a platinum plate $\left(0.28 \mathrm{~cm}^{2}\right)$ was used as the electrode substrate. The resulting polypyrrole film is denoted here as the $\mathrm{CHO} / \mathrm{Fc} / \mathrm{PPy}$ electrode.

The enzymatic activity of the CHO immobi-

Department of Applied Chemistry, Faculty of Engineering, Osaka University, Yamada-oka 2-1, Suita, Osaka 565

key word : polypyrrole, cholesterol sensor lized in the CHO/FC/PPy electrodes was determined by measuring absorbance at $240 \mathrm{~nm}$ which is characteristic absorption maximum of cholestenone formed by the following reaction 4 ).

$$
\begin{aligned}
& \text { Cholesterol }+\mathrm{O}_{2} \stackrel{\mathrm{CHO}}{\longrightarrow} \\
& \text { cholest-4-en-3-one }+\mathrm{H}_{2} \mathrm{O}_{2}
\end{aligned}
$$

The current response of the CHO/Fc/PPy electrodes was measured by the following procedure. The electrodes were polarized at $0.4 \mathrm{~V}$ vs. SCE in $0.1 \mathrm{M}$ deoxygenated phosphate buffer (20 $\left.\mathrm{cm}^{3}, \mathrm{pH}=7\right)$ containing Triton $\mathrm{X}-100(0.05 \%)$. After the anodic currents decayed to a constant value, 0.1 $\mathrm{cm}^{3}$ of 2-propanol containing cholesterol was added, followed by magnetic stirring for 30 s. Then the currents was measured in quiescent solutions.

\section{RESULTS AND DISCUSSIOH}

The CHO/Fc/PPy electrode prepared at the current density of $100 \mu \mathrm{A} \mathrm{cm} \mathrm{cm}^{-2}$ with the deposition charge of $100 \mathrm{mC} \mathrm{cm}^{-2}$ had the enzymatic activity of $6.1 \times 10^{-2} \mathrm{U} \mathrm{cm}^{-2}$. When the cholesterol solution was added to the phosphate buffer solution under polarization of this electrode, anodic currents were increased to give a steady value within a few minutes, indicating that the CHO/Fc/PPy electrode possesses the amperometric sensitivity to cholesterol.

Fig. 1 shows the effect of the current density utilized in the electropolymerization of pyrrole on the current response. The CHO/Fc/PPy electrodes showed the highest current response when they were prepared at 25-100 $\mu \mathrm{A} \mathrm{cm}^{-2}$, and with increasing or 


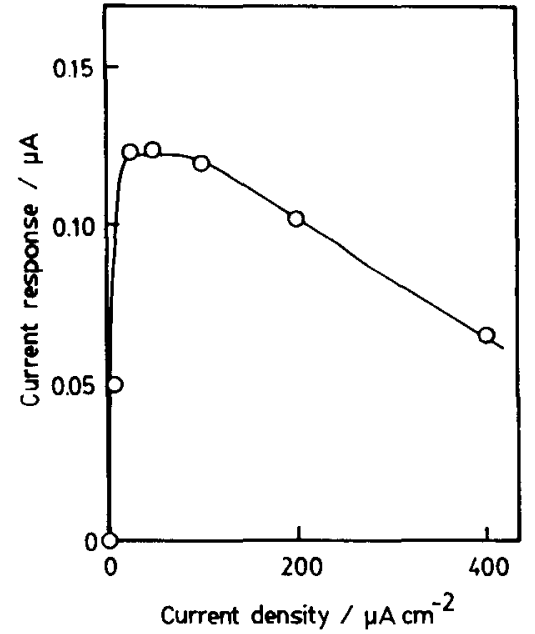

Fig. 1 Effect of current density in the electropolymerization on the current response at the resulting $\mathrm{CHO} / \mathrm{Fc} / \mathrm{PPy}$ electrodes measured in $0.1 \mathrm{mM}$ cholesterol. Deposition charge : $50 \mathrm{mC} \mathrm{cm}^{-2}$.

decreasing the current density from these values the current response of the resulting CHO/Fc/PPy electrodes was decreased. Two reasons are responsible for the decrease in the current response at a deposition current of PPy above $100 \mu \mathrm{A} \mathrm{cm}{ }^{-2}$. One is the degradation of resulting $\mathrm{PPy}$ films, because high anodic potential above $1.5 \mathrm{~V}$ vs. SCE was applied during the course of electropolymerization of pyrrole. The other is the apparent inactivation of $\mathrm{CHO}$, which was suggested by the decrease of the enzymatic activity for the deposition current above $100 \mu \mathrm{A} \mathrm{cm}^{-2}$ (for example, $1.8 \times 10^{-2} \mathrm{U} \mathrm{cm}^{-2}$ at $\left.400 \mu \mathrm{A} \mathrm{cm}^{-2}\right)$. Presently the main reason is still unknown. The decrease of the current response at the deposition current below $25 \mu \mathrm{A} \mathrm{cm} \mathrm{cm}^{-2}$ may result from the suppression of the diffusion of cholesterol in PPy films, because PPy films prepared at low current densities are usually very tight ${ }^{5)}$.

Fig. 2 shows a calibration curve of the $\mathrm{CHO} / \mathrm{Fc} / \mathrm{PPy}$ electrode prepared at the current density of $100 \mu \mathrm{A} \mathrm{cm}$ cm $^{-2}$ with the deposition charge of $50 \mathrm{mC} \mathrm{cm}{ }^{-2}$. The deviation of each point was $\pm 8 \%$. The current response was proportional to the cholesterol concentra-

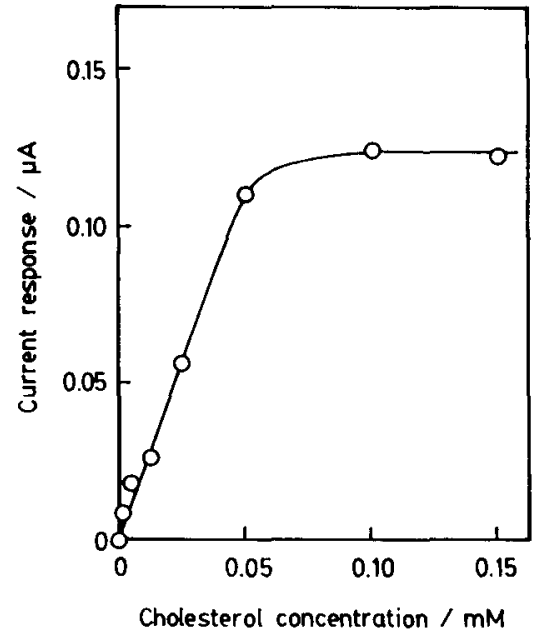

Fig. 2 Calibration curve of the CHO/Fc/PPy electrode prepared at $100 \mu \mathrm{A} \mathrm{cm}^{-2}$ for $50 \mathrm{mC}$ $\mathrm{cm}^{-2}$.

tion up to $0.05 \mathrm{mM}$, beyond which a saturation tendency appeared. If the $\mathrm{CHO} / \mathrm{Fc} / \mathrm{PPy}$ electrode was stored in $0.1 \mathrm{M}$ phosphate buffer at $4{ }^{\circ} \mathrm{C}$ and the current responses was measured intermittently, the CHO/Fc/PPy electrode showed stable current response for more than 12 days.

This work was supported by Grant-in-Aid for Scientific Research No. 63470066, from the Ministry of Education, Science and Culture.

\section{REFERTANCES}

1) B. Danielson and K. Mosbach, Methods in Enzymology, Vol. 137, Academic Press, New York, p 3-14 (1988).

2) C. Iwakura, Y.Kajiya, and H. Yoneyama, J. Chem. Soc., Chem. Commun., 1010 (1988).

3) Y. Kajiya, H. Sugai, C. Iwakura, and H. Yoneyama, Denki Kagaku, 56, 1110 (1988).

4) P. Roschlau, E. Berut, and W. Gruber, Methods of Enzymatic Analysis, p 1890, Academic Press, New York, (1974).

5) T. Osaka, K. Naoi, S. Ogano and $S$. Nakamura, J. Electrochem. Soc., 134, 2096 (1987). 